\title{
Peramalan Harga Komoditas Dengan Menggunakan Metode Arima-Garch
}

\author{
Ulil Azmi ${ }^{1}$, Wawan Hafid Syaifudin ${ }^{2}$ \\ 1,2Departemen Aktuaria, Institut Teknologi Sepuluh Nopember Surabaya, Indonesia \\ 1ulilazmi0211@gmail.com, 2wawan.hafid@gmail.com \\ DOI 10.30812/varian.v3i2.653
}

\begin{abstract}
INFO ARTIKEL
ABSTRAK

Riwayat Artikel:

Diterima: 11-03-2020

Disetujui: 08-04-2020

Kata Kunci:
Komoditas
Volatilitas
ARIMA
GARCH

Abstrak: Emas, Tembaga dan Minyak merupakan jenis komoditas yang banyak diincar oleh para investor untuk menanamkan modal dengan cara melakukan investasi pada jenis komoditas tersebut. Prediksi harga komoditas sangat bermanfaat bagi investor untuk melihat prospek investasi komoditas pada suatu perusahaan di masa yang akan datang. Harga komoditas memiliki karakteristik data yang tidak stabil atau sering disebut volatilitas. Untuk mengatasi permasalahan tersebut, dilakukan peramalan dengan metode ARIMA dan ARIMA-GARCH. Dipilih dua metode tersebut karena dua metode ini cocok untuk meramalkan sesuatu yang memiliki data history yang kuat. Metode ARIMA-GARCH lebih cocok digunakan untuk data-data yang memiliki volatilitas yang tinggi atau terdapat heteroskedastisitas pada residual data, sehingga hasil prediksi lebih akurat. Hal ini dibuktikan dengan nilai AIC lebih kecil dari pada hanya menggunakan metode ARIMA. Model terbaik untuk komoditas Emas adalah ARIMA(0,1,1) - GARCH $(1,1)$ sedangkan komoditas tembaga memiliki model terbaik yaitu $\operatorname{ARIMA}(2,1,2)$ GARCH $(1,2)$ dan komoditas minyak yaitu ARIMA(1,1,1). Nilai MAPE (Mean Absolute Percentage Error) dari ketiga jenis komoditas (Emas, Tembaga dan Minyak) berturutturut adalah sebesar $0.5524,0.8958$ dan 1.8112
\end{abstract}




\section{A. LATAR BELAKANG}

Investasi merupakan salah satu kegiatan penanaman modal dengan periode tertentu yang dapat dilakukan oleh masyarakat untuk mencari dan mendapakan keuntungan. Selama sepuluh hingga lima belas tahun terakhir ini, minat terhadap komoditas sebagai alternatif dalam berinvestasi makin meningkat. Komoditas memiliki karakteristik risiko yang berbeda dari investasi pasar modal aset lain seperti saham, obligasi dan mata uang.

Komoditas adalah suatu kelas aset yang tidak homogen dengan risiko dan return kemungkinan berbeda secara substansial antar komoditas. Komoditas dipengaruhi oleh kondisi permintaan dan penawaran. Komoditas dapat dikelompokkan ke dalam tiga kategori, yaitu komoditas energi, komoditas logam dan komoditas pertanian. Contoh komoditas energi adalah minyak, gas, batu bara, dan lain-lain. Komoditas Logam diantaranya adalah Emas, Tembaga dan Perak. Untuk komoditas pertanian contoh produk yang diperjual belikan adalah kopi, jagung, kapas, minyak kelapa sawit, dan lain-lain. Dari beberapa jenis komoditas tersebut, yang paling ramai diperdagangkan adalah komoditas energi dan logam berharga. Contohnya adalah Minyak, Tembaga dan Emas.

Pergerakan harga komoditas selalu mengalami perubahan dari waktu ke waktu serta melibatkan proses stokastik didalamnya. Prediksi harga komoditas sangat bermanfaat bagi investor untuk melihat prospek investasi komoditas pada suatu perusahaan di masa yang akan datang. Hasil prediksi harga komoditas ini akan membantu investor dalam mengantisipasi naik atau turunnya harga komoditas, sehingga investor dapat mengambil keputusan untuk membeli, menahan, atau menjual komoditas dari suatu perusahaan.

Data di sektor keuangan seperti harga komoditas biasanya bersifat sangat acak (random) dan memiliki volatilitas yang tinggi atau varians error tidak konstan (heteroskedastisitas). Salah satu metode yang dapat digunakan dalam memprediksi harga komoditas, di mana pergerakan harga komoditas menunjukkan pergerakan acak, adalah metode Autoregressive Integrated Moving Average (ARIMA) dan untuk mengatasi kondisi heteroskedastisitas pada varians error nya menggunakan model GARCH (Generalized Autoregrresive Conditional Heteroskedasticity). Oleh karena itu, penelitian ini akan menggabungkan dua model ARIMAGARCH untuk melakukan peramalan harga komoditas.

Penelitian mengenai peramalan harga komoditas dengan menggunakan ARIMA telah banyak dilakukan oleh peneliti terdahulu. Salah satunya adalah KumarMahto (2019) yang melakukan peramalan pada harga komoditas pertanian di India menggunakan metode ARIMA. Hasil penelitian tersebut menunjukkan bahwa model ARIMA (1,1,2) adalah model terbaik dengan MAPE sebesar 2,3\%. Selanjutnya, Guha (2016) melakukan peramalan pada harga emas di India. Hasilnya model terbaik adalah ARIMA $(1,1,1)$ dan MAPE sebesar 3,45. Selain itu, Nochai dan Titida (2006) melakukan peramalan harga minyak di Thailand memperoleh model terbaik adalah AR(3). Pada power systems, Metode ARIMA juga digunakan untuk meramalkan beban oleh Gross dan Galiana (1987) hasilnya adalah metode ARIMA mampu meramalkan dengan hasil yang baik.

Pada beberapa hasil penelitian terkadang ditemukan masalah pada residual model ARIMA yang terindikasi adanya heteroskedastik dalam variansi residualnya. Maka salah satu solusinya adalah menggunakan metode ARIMA-GARCH. Penelitian sebelumnya yang dilakukan oleh Faustina (2016) dan Weiss (2000) telah membuktikan bahwa model ARIMA-GARCH baik untuk menyelesaikan permasalahan pada data series yang mempunyai sifat volatilitas yang tinggi. Beberapa penelitian lainnya juga pernah dilakukan oleh Abledu (2012) tentang peramalan harga minyak di Ghana dan Puspatika (2018) meramalkan harga cabai dengan ARIMA-GARCH menghasilkan kesimpulan bahwa penggunaan metode ARIMA-GARCH mendapatkan hasil peramalan yang lebih baik dibandingkan dengan ARIMA dengan MAPE dan MSE yang lebih kecil. Karena pertimbangan tersebut, maka metode peramalan yang kami gunakan untuk penelitian kali ini adalah dengan menggunakan ARIMA-GARCH untuk meramalkan harga komoditas. 


\section{B. TINJAUAN PUSTAKA}

\section{Komoditas}

Komoditas adalah sesuatu benda nyata yang relatif mudah diperdagangkan, dapat diserahkan secara fisik, dapat disimpan untuk suatu jangka waktu tertentu dan dapat dipertukarkan dengan produk lainnya dengan jenis yang sama, yang biasanya dapat dibeli atau dijual oleh investor melalui bursa berjangka. Menurut Muttaqiena, A. (2015), Komoditas sering digolongkan dalam dua tipe, yaitu hard commodity dan soft commodity. Hard commodity digunakan untuk menyebut komoditas yang diambil dari alam melalui aktivitas pertambangan atau ekstraksi, seperti minyak, emas, dan lain-lain. Soft commodity mengacu pada komoditas agrikultur atau peternakan, seperti jagung, gandum, kopi, gula, dan lain-lain.

\section{Autoregressive Integrated Moving Average (ARIMA)}

Model Autoregressive Integrated Moving Average (ARIMA) tingkat $p$ dan $q$, ARIMA(p,d,q) adalah model untuk sebuah data deret waktu yang tidak stasioner dan tidak musiman. Diberikan $\mathbf{Z}_{\mathbf{t}}$ dan $\mathbf{a}_{\mathbf{t}}$ adalah nilai yang diamati dan random error pada periode $t$, dengan $\mu$ adalah rata-rata model $, \boldsymbol{\phi}_{\mathbf{1}}, \boldsymbol{\phi}_{2}, \ldots \boldsymbol{\phi}_{\mathbf{p}}$ adalah parameter autoregressive dengan tingkat $p, \boldsymbol{\theta}_{\mathbf{1}}, \boldsymbol{\theta}_{2}, \ldots \boldsymbol{\theta}_{\mathbf{q}}$ adalah parameter moving average dengan tingkat $q$, dan $d$ adalah tingkat pembeda agar proses menjadi stasioner. Persamaan umum dari ARIMA (p,d,q) menurut Box Jenkins (1994) dengan rata-rata $\mu$ adalah sebagai berikut :

$$
\phi_{p}(B)(1-B)^{d} Z_{t}=\mu+\theta_{q}(B) a_{t}
$$

Dimana,

$\emptyset_{p}(B)=1-\emptyset_{1} B-\emptyset_{2} B^{2}-\ldots-\emptyset_{p} B^{p}$

$\theta_{q}(B)=1-\theta_{1} B-\theta_{2} B^{2}-\ldots-\theta_{q} B^{q}$

B adalah operator langkah mundur dimana $\boldsymbol{B}^{\boldsymbol{j}} \boldsymbol{Z}_{\boldsymbol{t}}=\boldsymbol{Z}_{\boldsymbol{t}-\boldsymbol{j}}$

Ada beberapa kriteria pemilihan model yang dapat digunakan untuk memilih model ARIMA terbaik pada suatu data runtun waktu, antara lain Akaike's Information Criterion (AIC), AIC Bias Corrected (AICc), dan Schwarz's Information Criterion (SIC). Berikut adalah rumus untuk perhitungan ketiga kriteria tersebut (Suhartono, 2008):

Rumus perhitungan Akaike's Information Criterion (AIC) adalah sebagai berikut :

$$
A I C=\ln \widehat{\sigma}_{k}^{2}+\frac{n+2 k}{n}
$$

dengan $k$ adalah banyaknya parameter model dan $n$ adalah jumlah data (pengamatan), serta $\widehat{\sigma}_{k}^{2}$ adalah estimator maksimul likelihood dari varians error yang didefinisikan sebagai berikut:

$$
\widehat{\sigma}_{k}^{2}=\frac{R S S_{k}}{n}
$$

dengan RSS adalah the Residual sum of Square (Jumlah Kuadrat Error). Kemudian untuk rumus perhitungan AIC Bias Corrected (AICc) adalah

$$
A I C c=\ln \widehat{\sigma}_{k}^{2}+\frac{n+k}{n-k-2}
$$

Sedangkan Schwarz's Information Criterion (SIC) memiliki rumus perhitungan sebagai berikut :

$$
S I C=\ln \widehat{\sigma}_{k}^{2}+\frac{k \ln n}{n}
$$


dengan $k$ adalah banyaknya parameter model dan $n$ adalah jumlah data (pengamatan), serta $\widehat{\sigma}_{k}^{2}$ adalah estimator maksimul likelihood dari varians error

\section{Generalized Autoregrresive Conditional Heteroscedasticity (GARCH)}

Metode Generalized Autoregrresive Conditional Heteroscedasticity atau disingkat GARCH yang dikembangkan oleh Bollerslev tahun 1986 adalah suatu metode yang berasal dari pengembangan metode Autoregrresive Conditional Heteroscedasticity (ARCH). Identifikasi orde pada GARCH bisa juga dilakukan dengan melihat pola ACF dan PACF dari data time series. Proses GARCH didefinisikan oleh persamaan sebagai berikut :

$$
\sigma_{t}^{2}=\alpha_{0}+\sum_{i=1}^{r} \alpha_{i} a_{t-i}^{2}+\sum_{i=1}^{s} \beta_{i} \sigma_{t-i}^{2}
$$

Dimana $\sigma_{t}^{2}$ adalah kondisional varians dari $y_{t}, \alpha_{0}>0$ dan $\sum_{i=1}^{\max (r, s)}\left(\alpha_{i}+\beta_{i}\right)<1$. Selanjutnya, $\alpha_{i}$ dan $\beta_{i}$ adalah koefisien parameter dari ARCH dan GARCH. ACF dan PACF dari residual dapat membantu mengidentifikasi tingkat $r$ dan s pada ARCH dan GARCH. (Bolerslev, 1986).

\section{METODE PENELITIAN}

Data harga komoditas yang digunakan dalam penelitian ini adalah data sekunder yang diperoleh dari website www.markets.businessinsider.com/commodities. Jenis komoditas yang digunakan dalam penelitian ini adalah Emas, Minyak dan Tembaga. Satuan harga yang digunakan pada ketiga jenis Komoditas tersebut adalah USD. Data yang digunakan adalah data closing harian pada periode Januari 2019 sampai Januari 2020. Data dibagi menjadi dua bagian yaitu data in-sample (Januari 2019 - Desember 2019) dan data Out-Sample (Januari 2020).

Software yang digunakan dalam penelitian ini adalah E-Views 6. Langkah-langkah analisis pada penelitian ini yang pertama adalah pengumpulan data sekunder dan membagi data menjadi data in-sample dan data out-of-sample. Tahapan penelitian selanjutnya adalah dengan menggunakan data in-sample melakukan tahapan-tahapan sebagai berikut :

1. Mendeskripsikan masing-masing data dengan membuat plotting time series.

2. Menguji kestasioneritasan data dengan menggunakan uji akar unit, dan Uji Correlogram ACF dan PACF

3. Melakukan proses differencing data, jika data belum stasioner

4. Melakukan Identifikasi model ARIMA berdasarkan pola ACF dan PACF nya.

5. Melakukan Estimasi parameter model ARIMA

6. Melakukan uji diagnosis model ARIMA

7. Mengidentifikasi ada tidaknya heteroskedastisitas pada residual model ARIMA.

8. Melakukan estimasi model ARCH/GARCH

9. Evaluasi model ARIMA-GARCH terbaik berdasarkan nilai AIC terkecil

10. Melakukan prediksi harga komoditas dengan menggunakan data out-of-sample dan membandingkan nilai MAPE (Mean Absolute Percentage Error)

\section{HASIL DAN PEMBAHASAN}

Pada penelitian ini, akan dilakukan identifikasi dengan model ARIMA terlebih dahulu, kemudian akan dianalisis residual model ARIMA apakah ada heteroskedastisitas atau tidak, jika ada masalah heteroskedastisitas, maka pemodelan akan dilanjutkan dengan GARCH. 
Berikut adalah grafik masing-masing harga closing untuk komoditas Emas, Minyak dan Tembaga periode Tahun 2019.

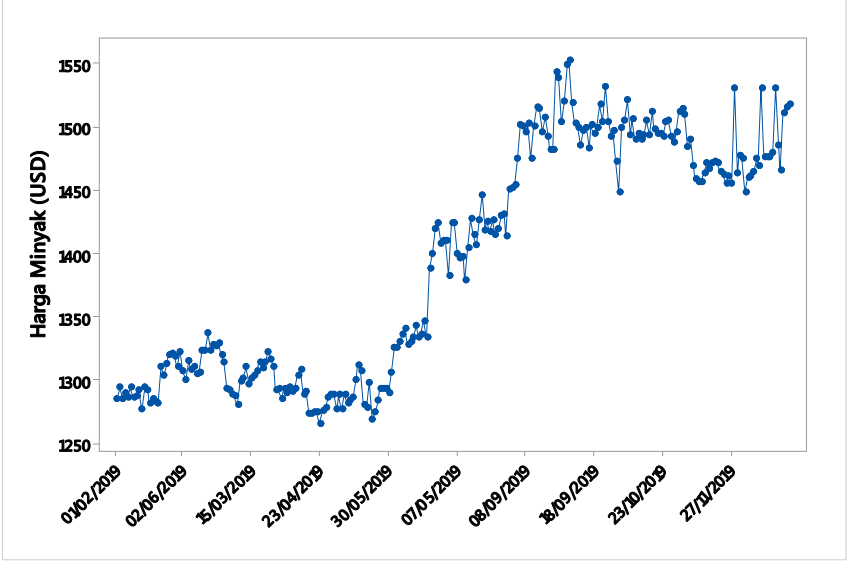

Gambar 1. Time Series Plot Data Harga Closing Emas (harga dalam USD)

Gambar 1 menunjukkan bahwa harga komoditas awalnya cenderung berfluktuasi mulai periode Januari - Mei 2019, kemudian mulai meningkat tajam pada sekitar pertengahan bulan Juni hingga September 2019, dan kembali berfluktuasi hingga akhir periode tahun 2019.

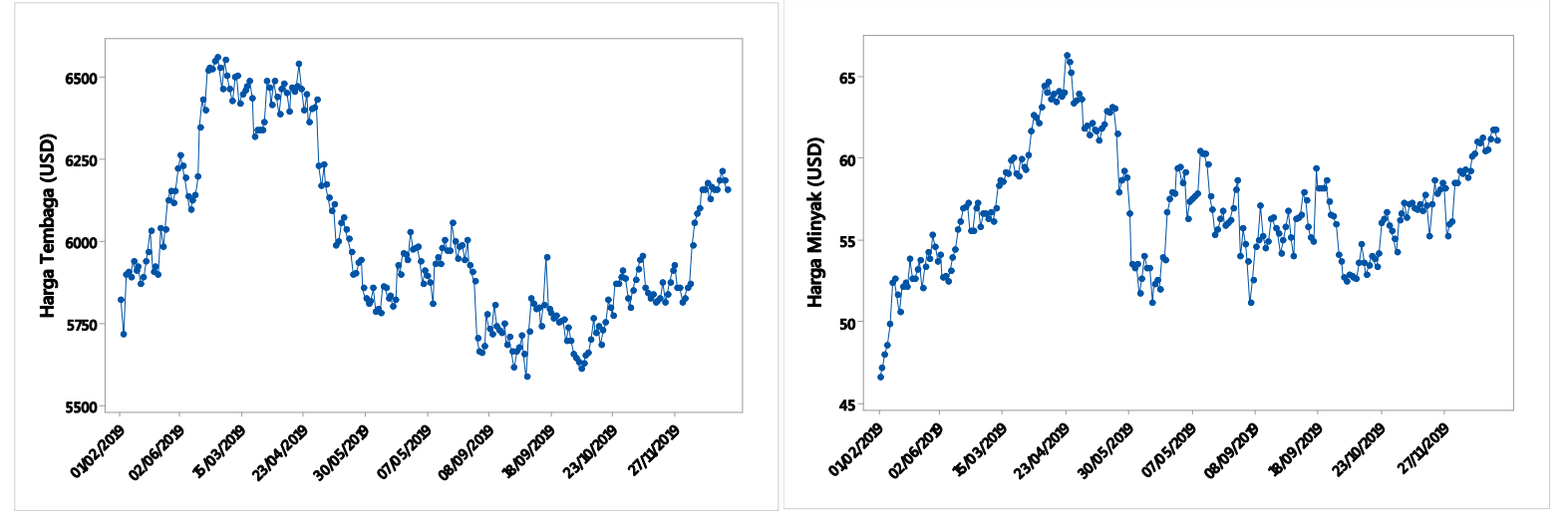

Gambar 2. Time Series Plot Data Harga Closing (harga dalam USD) (a) Tembaga (b) Minyak

Gambar 2 secara berurutan menunjukkan pola data harga komoditas Tembaga dan Minyak periode tahun 2019. Keduanya menunjukkan pola pergerakan yang hampir sama, yaitu mulai awal periode harga semakin naik dan mencapai puncak tertinggi pada sekitar bulan April 2019, kemudian kembali menurun dan berfluktuasi (naik dan turun) mulai bulan Mei hingga akhir periode tahun 2019.

Berdasarkan pola grafik tersebut, dapat dikatakan bahwa data komoditas Emas belum stasioner terhadap rata-rata, untuk menguji pernyataan tersebut dilakukan pengujian stasioneritas dengan uji akar unit sebagai berikut :

Diberikan sebuah hipotesis sebagai berikut H0 : Harga komoditas memiliki akar unit (data tidak stasioner) H1 : Harga komoditas tidak memiliki akar unit (data stasioner) ditetapkan alpha sebesar 0,05 atau $\alpha=0,05$ 
Berdasarkan hasil output dengan menggunakan uji unit akar, menghasilkan nilai sebagai berikut :

Tabel 1. Nilai p dari Tes Augmented Dickey-Fuller

\begin{tabular}{cll}
\hline No & \multicolumn{1}{c}{$\begin{array}{c}\text { Jenis } \\
\text { Komoditas }\end{array}$} & Nilai $\mathbf{p}$ \\
\hline $\mathbf{1}$ & Emas & 0.8188 \\
$\mathbf{2}$ & Tembaga & 0.4287 \\
$\mathbf{3}$ & Minyak & 0.0217 \\
\hline
\end{tabular}

Berdasarkan Tabel 1 menunjukkan bahwa nilai p untuk Emas dan Tembaga memiliki nilai lebih besar dari 0,05 atau nilai $\mathrm{p}>\alpha$, maka keputusan yang diambil adalah Gagal tolak Ho artinya harga komoditas memiliki akar unit atau data belum stasioner. Tetapi, untuk komoditas Minyak jika dilihat dari nilai p, data sudah stasioner, tetapi kita uji kembali dengan melihat pola ACF DAN PACF data aktual seperti gambar dibawah ini :

\begin{tabular}{|c|c|c|c|c|c|c|c|}
\hline \multicolumn{2}{|c|}{ Autocorrelation } & Partial Correlation & & $A C$ & PAC & Q-Stat & Prob \\
\hline & 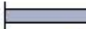 & 长 & 1 & 0.933 & 0.933 & 216.87 & 0.000 \\
\hline & 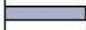 & 111 & 2 & 0.870 & -0.009 & 405.98 & 0.000 \\
\hline & 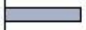 & $1 / 1$ & 3 & 0.815 & 0.036 & 572.82 & 0.000 \\
\hline & 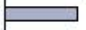 & 10 & 4 & 0.769 & 0.040 & 722.03 & 0.000 \\
\hline & & 111 & 5 & 0.723 & -0.022 & 854.38 & 0.000 \\
\hline & 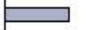 & 10 & 6 & 0.687 & 0.058 & 974.19 & 0.000 \\
\hline & 口 & 111 & 7 & 0.654 & 0.015 & 1083.3 & 0.000 \\
\hline & 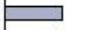 & 10 1 & 8 & 0.617 & -0.040 & 1180.9 & 0.000 \\
\hline & $\Longrightarrow$ & 101 & 9 & 0.578 & -0.028 & 1266.9 & 0.000 \\
\hline & 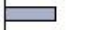 & 101 & 10 & 0.538 & -0.032 & 1341.6 & 0.000 \\
\hline & $\square$ & 111 & 11 & 0.503 & 0.015 & 1407.2 & 0.000 \\
\hline & 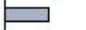 & 11 & 12 & 0.468 & -0.016 & 1464.3 & 0.000 \\
\hline & 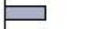 & 111 & 13 & 0.438 & 0.015 & 1514.7 & 0.000 \\
\hline & 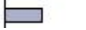 & d 1 & 14 & 0.398 & -0.101 & 1556.3 & 0.000 \\
\hline
\end{tabular}

Gambar 3. ACF dan PACF data harga komoditas Minyak

Gambar 3 menunjukkan bahwa data harga komoditas Minyak belum stasioner, Maka data pada seluruh jenis komoditas perlu dilakukan proses differencing. Setelah dilakukan proses differencing satu kali, didapatkan bahwa data sudah stasioner. Kemudian dilakukan dugaan model sementara dengan melihat plot ACF dan PACF.

\begin{tabular}{|c|c|c|c|c|c|c|}
\hline Autocorrelation & Partial Correlation & & $A C$ & PAC & Q-Stat & Prob \\
\hline$\square_{1}$ & $\dot{\theta l}_{1}$ & & -0.289 & -0.289 & 20.748 & 0.000 \\
\hline 10 & 미 & & -0.083 & -0.182 & 22.452 & 0.000 \\
\hline וקו & 101 & 3 & 0.042 & -0.044 & 22.897 & 0.000 \\
\hline 10 & 1 & 4 & -0.045 & -0.067 & 23.399 & 0.000 \\
\hline 101 & 111 & 5 & 0.028 & -0.004 & 23.599 & 0.000 \\
\hline 101 & 10 & 6 & -0.060 & -0.072 & 24.499 & 0.000 \\
\hline 101 & ( 1 & 7 & -0.049 & -0.099 & 25.106 & 0.001 \\
\hline ibl & 101 & 8 & 0.098 & 0.035 & 27.539 & 0.001 \\
\hline 다 & 당 & 9 & -0.165 & -0.159 & 34.511 & 0.000 \\
\hline ק证 & , & 10 & 0.173 & 0.095 & 42.173 & 0.000 \\
\hline 101 & 101 & 11 & -0.063 & -0.032 & 43.210 & 0.000 \\
\hline 111 & 111 & 12 & -0.023 & -0.015 & 43.346 & 0.000 \\
\hline ומלו & 111 & 13 & 0.058 & 0.016 & 44.214 & 0.000 \\
\hline $1 \sqrt{1}$ & 111 & 14 & -0.014 & 0.020 & 44.263 & 0.000 \\
\hline
\end{tabular}

Gambar 4. Plot ACF dan PACF data differencing komoditas Emas

Dugaan model ARIMA untuk komoditas Emas jika dilihat dari pola ACF dan PACF nya sesuai dari Gambar 4, adalah ARIMA(0,1,1), ARIMA(1,1,0) dan ARIMA(1,1,1). 


\begin{tabular}{|c|c|c|c|c|c|c|}
\hline Autocorrelation & Partial Correlation & & $A C$ & PAC & Q-Stat & Prob \\
\hline 叫 1 & 叫 1 & 1 & -0.086 & -0.086 & 1.8475 & 0.174 \\
\hline 1 & 1 & 2 & -0.096 & -0.105 & 4.1562 & 0.125 \\
\hline ו 1 1 & ין 1 & 3 & 0.090 & 0.073 & 6.1976 & 0.102 \\
\hline $1 \mid 1$ & $1 \mid 1$ & 4 & 0.015 & 0.020 & 6.2547 & 0.181 \\
\hline 101 & 101 & 5 & -0.070 & -0.052 & 7.4758 & 0.188 \\
\hline 10 & $1 \mid 1$ & 6 & 0.033 & 0.019 & 7.7519 & 0.257 \\
\hline 呵 & 1日 & 7 & 0.149 & 0.144 & 13.430 & 0.062 \\
\hline ㄷ. & ㄷ. 1 & 8 & -0.149 & -0.115 & 19.121 & 0.014 \\
\hline 10 1 & 101 & 9 & -0.031 & -0.032 & 19.368 & 0.022 \\
\hline ון ו 1 & 101 & 10 & 0.090 & 0.040 & 21.445 & 0.018 \\
\hline 101 & \begin{tabular}{l|l}
1 & 1
\end{tabular} & 11 & -0.030 & -0.007 & 21.681 & 0.027 \\
\hline 111 & 10 & 12 & -0.011 & 0.018 & 21.709 & 0.041 \\
\hline בי & ין ו & 13 & 0.115 & 0.091 & 25.182 & 0.022 \\
\hline ינן & ין 1 & 14 & 0.068 & 0.075 & 26.401 & 0.023 \\
\hline
\end{tabular}

Gambar 5. Plot ACF dan PACF data differencing komoditas Tembaga

Dugaan model ARIMA untuk komoditas Tembaga jika dilihat dari pola ACF dan PACF nya sesuai dari Gambar 5, adalah ARIMA(0,1,1), ARIMA(1,1,0) dan $\operatorname{ARIMA(2,1,2).~}$

\begin{tabular}{|c|c|c|c|c|c|c|}
\hline Autocorrelation & Partial Correlation & & $A C$ & PAC & Q-Stat & Prob \\
\hline Id 1 & Id 1 & 1 & -0.027 & -0.027 & 0.1757 & 0.675 \\
\hline 叫 1 & 他 1 & 2 & -0.069 & -0.070 & 1.3611 & 0.506 \\
\hline 他 1 & 叫 1 & 3 & -0.067 & -0.071 & 2.4888 & 0.477 \\
\hline 101 & 10 & 4 & 0.053 & 0.045 & 3.2061 & 0.524 \\
\hline 111 & 111 & 5 & -0.016 & -0.023 & 3.2705 & 0.658 \\
\hline 101 & 101 & 6 & -0.044 & -0.044 & 3.7679 & 0.708 \\
\hline $1 \mid 1$ & $1 \mid 1$ & 7 & 0.010 & 0.012 & 3.7950 & 0.803 \\
\hline 111 & 111 & 8 & -0.014 & -0.025 & 3.8434 & 0.871 \\
\hline 1 & 1 & 9 & 0.074 & 0.071 & 5.2335 & 0.813 \\
\hline 101 & 101 & 10 & -0.047 & -0.041 & 5.8016 & 0.832 \\
\hline \begin{tabular}{l|l}
1 & 1
\end{tabular} & \begin{tabular}{l|l}
1 & 1
\end{tabular} & 11 & -0.003 & -0.001 & 5.8044 & 0.886 \\
\hline 111 & 111 & 12 & 0.013 & 0.018 & 5.8463 & 0.924 \\
\hline 1 & 10 & 13 & 0.063 & 0.052 & 6.8852 & 0.908 \\
\hline 19 & יקו & 14 & 0.057 & 0.069 & 7.7319 & 0.903 \\
\hline
\end{tabular}

Gambar 6. Plot ACF dan PACF data differencing komoditas Minyak

Dugaan model ARIMA untuk komoditas Minyak jika dilihat dari pola ACF dan PACF nya sesuai dari Gambar 6, adalah ARIMA(1,1,1) dan ARIMA(2,1,1).

Untuk menentukan model terbaik dari beberapa dugaan tersebut, maka dilakukan pengujian signifikansi parameter dan membandingkan nilai AIC terkecil. Estimasi model menggunakan data insampel. Diperoleh hasil estimasi parameter dan nilai AIC untuk masing-masing komoditas.

Tabel 2. Estimasi dan Uji Signifikansi Parameter Model ARIMA Data Komoditas Emas

\begin{tabular}{lcccc}
\hline Model & Parameter & $\begin{array}{c}\text { Koefisien } \\
\text { Parameter }\end{array}$ & Nilai P & AIC \\
\hline ARIMA* & MA(1) & -0.377135 & 0.0000 & 8.412469 \\
$\mathbf{( 0 , 1 , 1 )}$ & & & & \\
\hline ARIMA & AR(1) & -0.285436 & 0.0000 & 8.444740 \\
$\mathbf{( 1 , 1 , 0 )}$ & & & & \\
\hline ARIMA & AR(1) & 0.220377 & 0.1637 & 8.417987 \\
$\mathbf{( 1 , 1 , 1 )}$ & MA(1) & -0.569943 & 0.0000 & \\
\hline
\end{tabular}

Berdasarkan tabel 2 dapat diketahui bahwa model ARIMA $(0,1,1)$ dan ARIMA $(1,1,0)$ yang memiliki parameter signifikan karena nilai-p pada koefisien MA dan AR kurang dari nilai $\alpha=0,05$. Dilihat dari AIC nya, model ARIMA $(0,1,1)$ memiliki nilai yang lebih kecil dibandingkan dengan model ARIMA lainnya. Sehingga model terbaik untuk komoditas emas yang dipilih adalah ARIMA $(0,1,1)$. 
Tabel 3. Estimasi dan Uji Signifikansi Parameter Model ARIMA Data Komoditas Tembaga

\begin{tabular}{ccccc}
\hline Model & Parameter & $\begin{array}{c}\text { Koefisien } \\
\text { Parameter }\end{array}$ & Nilai P & AIC \\
\hline ARIMA & AR(1) & -0.085496 & 0.1793 & 10.87701 \\
$\mathbf{( 1 , 1 , 0 )}$ & & & & \\
\hline ARIMA & MA(1) & -0.105118 & 0.1002 & 10.88570 \\
$\mathbf{( 0 , 1 , 1 )}$ & & & & \\
\hline ARIMA* & AR(1) & -0.631475 & 0.0000 & 10.79513 \\
$\mathbf{( 2 , 1 , 2 )}$ & AR(2) & -0.975671 & 0.0000 & \\
& MA(1) & 0.631871 & 0.0000 & \\
& MA(2) & 0.985802 & 0.0000 & \\
\hline
\end{tabular}

Berdasarkan Tabel 3 dapat diketahui bahwa model yang memiliki parameter signifikan adalah ARIMA $(2,1,2)$ karena nilai-p pada koefisien MA dan AR kurang dari nilai $\alpha=0,05$. Dilihat dari AIC nya, model ARIMA $(2,1,2)$ memiliki nilai yang lebih kecil dibandingkan dengan model ARIMA lainnya. Sehingga model terbaik untuk komoditas tembaga yang dipilih adalah ARIMA $(2,1,2)$.

Tabel 4. Estimasi dan Uji Signifikansi Parameter Model ARIMA Data Komoditas Minyak

\begin{tabular}{ccrcc}
\hline Model & Parameter & $\begin{array}{c}\text { Koefisien } \\
\text { Parameter }\end{array}$ & Nilai P & AIC \\
\hline $\begin{array}{c}\text { *ARIMA } \\
\mathbf{( 1 , 1 , 1 )}\end{array}$ & AR(1) & 0.963576 & 0.0000 & 2.987792 \\
& MA(1) & -1.044161 & 0.0000 & \\
\hline ARIMA & AR(1) & 0.758400 & 0.0000 & 3.072300 \\
$\mathbf{( 2 , 1 , 1 )}$ & AR(2) & -0.021499 & 0.7468 & \\
& MA(1) & -0.804292 & 0.0000 & \\
\hline
\end{tabular}

Berdasarkan Tabel 4 dapat diketahui bahwa model yang memiliki parameter signifikan adalah model ARIMA $(1,1,1)$ karena nilai-p pada koefisien MA dan AR kurang dari nilai $\alpha=0,05$. Dilihat dari AIC nya, model ARIMA $(1,1,1)$ memiliki nilai yang lebih kecil dibandingkan dengan model ARIMA lainnya. Sehingga model terbaik untuk komoditas minyak yang dipilih adalah ARIMA $(1,1,1)$.

Selanjutnya adalah mengidentifikasi apakah residual mengandung heteroskedastisitas atau tidak, dengan menggunakan hipotesis sebagai berikut :

$\mathrm{H}_{0}$ : Tidak ada efek ARCH/GARCH pada harga Komoditas Minyak (homokedastik)

$\mathrm{H}_{1}$ : Ada efek ARCH/GARCH pada harga Komoditas Minyak (heteroskedastik)

dengan $\alpha=0,05$. 


\begin{tabular}{rrrr}
\hline Lag & $\begin{array}{c}\text { Prob } \\
\text { (Emas) }\end{array}$ & $\begin{array}{c}\text { Prob } \\
\text { (Tembaga) }\end{array}$ & $\begin{array}{c}\text { Prob } \\
\text { (Minyak) }\end{array}$ \\
\hline $\mathbf{3}$ & 0.002 & & \\
$\mathbf{4}$ & 0.009 & & 0.379 \\
$\mathbf{5}$ & 0.017 & & 0.154 \\
$\mathbf{6}$ & 0.021 & 0.060 & 0.133 \\
$\mathbf{7}$ & 0.038 & 0.156 & 0.231 \\
$\mathbf{8}$ & 0.053 & 0.003 & 0.219 \\
$\mathbf{9}$ & 0.086 & 0.005 & 0.095 \\
$\mathbf{1 0}$ & 0.125 & 0.011 & 0.117 \\
$\mathbf{1 1}$ & 0.010 & 0.015 & 0.173 \\
$\mathbf{1 2}$ & 0.016 & 0.023 & 0.199 \\
$\mathbf{1 3}$ & 0.019 & 0.030 & 0.261 \\
$\mathbf{1 4}$ & 0.029 & 0.036 & 0.333 \\
\hline
\end{tabular}

Berdasarkan uji ARCH-LM, untuk jenis komoditas Emas dan Tembaga menunjukkan bahwa pada semua lag memiliki nilai- $p<0,05$ artinya tolak $\mathrm{H}_{0}$ atau ada efek ARCH-GARCH (heteroskedastik). Sedangkan untuk komoditas minyak, menunjukkan bahwa pada semua lag memiliki nilai- $p>0,05$ artinya gagal tolak $\mathrm{H}_{0}$ atau tidak ada efek ARCH-GARCH (homoskedastik). Melalui hasil pengujian tersebut, dapat disimpulkan jenis komoditas Emas dan Tembaga mengandung unsur heteroskedastik, maka perlu dilakukan estimasi model dengan ARCH/GARCH.

Tabel 6. Estimasi dan Pengujian Parameter Model ARIMA-GARCH pada Harga Komoditas

\begin{tabular}{|c|c|c|c|c|}
\hline Model & Parameter & $\begin{array}{l}\text { Koefisien } \\
\text { Parameter }\end{array}$ & Nilai P & AIC \\
\hline \multicolumn{5}{|c|}{ Komoditas Emas } \\
\hline \multirow[t]{2}{*}{$\begin{array}{l}\text { *ARIMA } \\
(0,1,1)\end{array}$} & MA(1) & -0.260092 & 0.0000 & 8.183355 \\
\hline & Konstanta & 0.791386 & 0.0503 & \\
\hline GARCH & $\operatorname{RESID}^{2}(1)$ & -0.032500 & 0.0036 & \\
\hline$(1,1)$ & GARCH(1) & 1.039816 & 0.0000 & \\
\hline $\begin{array}{l}\text { ARIMA } \\
(0,1,1)\end{array}$ & MA(1) & -0.295763 & 0.0000 & 8.235779 \\
\hline GARCH & Konstanta & 0.789452 & 0.0555 & \\
\hline$(0,1)$ & GARCH(1) & 1.005538 & 0.0000 & \\
\hline \multicolumn{5}{|c|}{$\begin{array}{l}\text { Komoditas } \\
\text { Tembaga }\end{array}$} \\
\hline ARIMA & $\operatorname{AR}(1)$ & -0.622723 & 0.0000 & 10.80123 \\
\hline \multirow[t]{3}{*}{$(2,1,2)$} & $\operatorname{AR}(2)$ & -0.977405 & 0.0000 & \\
\hline & MA(1) & 0.621892 & 0.0000 & \\
\hline & $\mathrm{MA}(2)$ & 0.927597 & 0.0000 & \\
\hline
\end{tabular}




\begin{tabular}{rcrrr}
\hline & Konstanta & 4212.180 & 0.0000 & \\
GARCH & RESID $^{2}(1)$ & 0.130762 & 0.0016 & \\
$\mathbf{( 1 , 1 )}$ & GARCH(1) & -0.636398 & 0.0000 & \\
\hline *ARIMA & AR(1) & -0.625201 & 0.0000 & 10.77528 \\
$\mathbf{( 2 , 1 , 2 )}$ & AR(2) & -0.972590 & 0.0000 & \\
& MA(1) & 0.626723 & 0.0000 & \\
& MA(2) & 0.985311 & 0.0000 & \\
& & & & \\
GARCH & RESID $2(1)$ & -0.035564 & 0.0030 & \\
$\mathbf{( 1 , 2 )}$ & GARCH(1) & 1.582309 & 0.0000 & \\
& GARCH(2) & -0.956285 & 0.0000 & \\
\hline
\end{tabular}

Berdasarkan Tabel 6 diperoleh hasil bahwa model ARIMA-GARCH yang terbaik adalah yang memiliki parameter yang signifikan, atau nilai p kurang dari 0,05. Dan memiliki nilai AIC yanglebih kecil. Maka, untuk komoditas emas, model terbaiknya adalah ARIMA(0,1,1) - GARCH(1,1) sedangkan komoditas tembaga memiliki model terbaik yaitu ARIMA(2,1,2) - GARCH(1,2).

Model yang telah diperoleh sudah tidak mengandung unsur heteroskedastisitas, hal ini dibuktikan dengan hasil uji asumsi residual pada Tabel 7, dimana nilai probabilitas (nilai-p) lebih dari 0.05 artinya gagal tolak H0 atau tidak ada efek ARCH-GARCH (heteroskedastik).

Tabel 7. Hasil uji asumsi heteroskedastisitas dari residual

\begin{tabular}{|c|c|c|c|c|c|c|c|c|c|c|c|c|}
\hline Lag & 2 & 3 & 4 & 5 & 6 & 7 & 8 & 9 & 10 & 11 & 12 & 13 \\
\hline$p$-Emas & 0,184 & 0,229 & 0,366 & 0,501 & 0,628 & 0,448 & 0,565 & 0,667 & 0,753 & 0,738 & 0,58 & 0,663 \\
\hline$p$-Tembaga & & & & 0,083 & 0,179 & 0,04 & 0,077 & 0,102 & 0,137 & 0,193 & 0,201 & 0,254 \\
\hline
\end{tabular}

Tahapan selanjutnya adalah melakukan prediksi harga komoditas sesuai dengan model ARIMA-GARCH yang sudah diperoleh sebelumnya. Prediksi dilakukan adalah untuk periode 1 bulan kedepan dengan menggunakan data out of sample, yaitu data bulan Januari 2020. Kemudian, data aktual dibandingkan dengan data hasil prediksi sehingga diperoleh nilai MAPE.

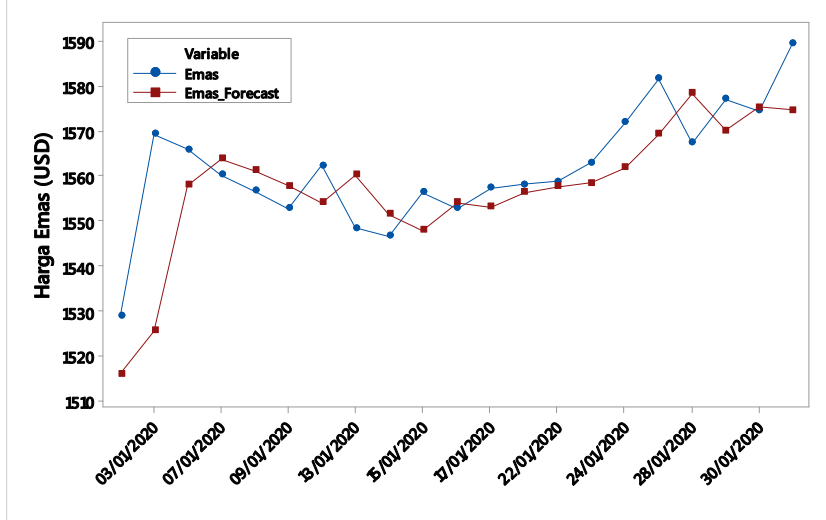

(a)

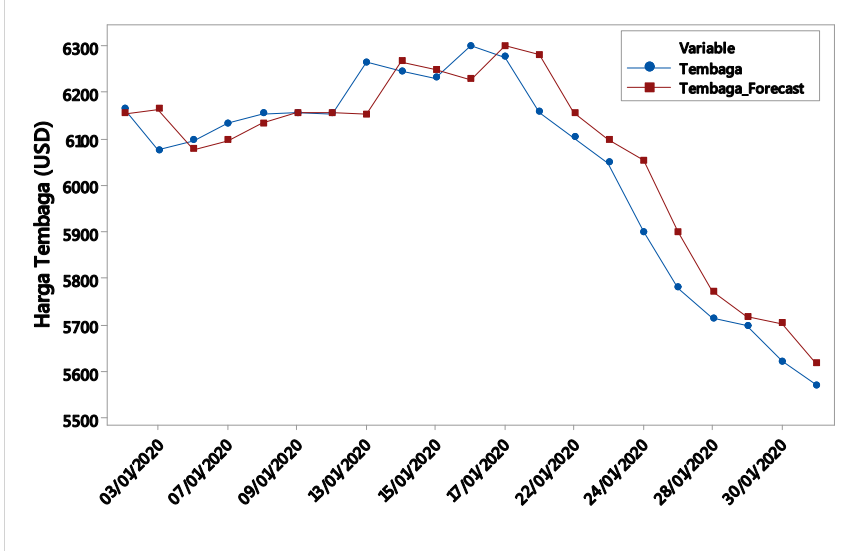

(b) 


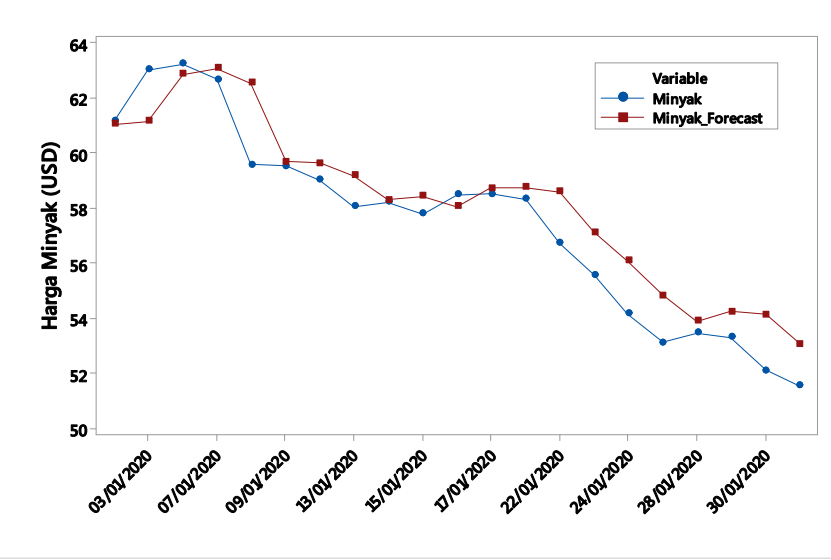

(c)

Gambar 7. Hasil Prediksi Harga Komoditas

(a) Komoditas Emas (b) Komoditas Tembaga

(c) Komoditas Minyak

Berdasarkan Gambar 7 dapat dilihat bahwa hasil ramalan tidak berbeda secara signifikan dan mengikuti pola yang sama dengan data aktual, hal ini menunjukkan bahwa model yang diperoleh sudah cukup baik untuk dilakukan proses estimasi harga komoditas untuk periode ke depannya. Selain itu dapat dilihat nilai MAPE (Mean Absolute Percentage Error) nya untuk melihat seberapa besar error dari hasil peramalan yang diperoleh tersebut pada tabel dibawah ini.

Tabel 8. Nilai MAPE dari Hasil Peramalan Harga Komoditas

\begin{tabular}{lcc}
\hline \multicolumn{1}{c}{ Komoditas } & \multicolumn{2}{c}{ Nilai MAPE } \\
\hline Emas & ARIMA & ARIMA-GARCH \\
Tembaga & 0.5664 & $0.5524^{*}$ \\
Minyak & 0.9029 & $0.8958^{*}$ \\
& 1.8112 & -
\end{tabular}

Tabel 8 menunjukkan hasil bahwa nilai MAPE (Mean Absolute Percentage Error) pada model ARIMAGARCH untuk komoditas Emas dan Tembaga memiliki nilai yang lebih kecil dibandingkan dengan nilai MAPE pada model ARIMA. Sehingga dapat disimpulkan bahwa nilai prediksi yang dihasilkan sudah cukup baik. Adapun nilai MAPE dari ketiga jenis komoditas (Emas, Tembaga dan Minyak) berturut-turut adalah sebesar 0.5524, 0.8958 dan 1.8112

\section{E. SIMPULAN DAN SARAN}

Metode ARIMA-GARCH lebih cocok digunakan untuk data-data yang memliki volatilitas yang tinggi atau terdapat heteroskedastisitas pada residual data, sehingga hasil prediksi lebih akurat. Hal ini dibuktikan dengan nilai AIC lebih kecil dari pada hanya menggunakan metode ARIMA. Model terbaik untuk komoditas Emas adalah ARIMA(0,1,1) - GARCH(1,1) sedangkan komoditas tembaga memiliki model terbaik yaitu ARIMA(2,1,2) - GARCH(1,2) dan komoditas minyak yaitu ARIMA $(1,1,1)$. Nilai MAPE (Mean Absolute Percentage Error) dari ketiga jenis komoditas (Emas, Tembaga dan Minyak) berturut-turut adalah sebesar $0.5524,0.8958$ dan 1.8112

Saran yang dapat diajukan oleh penulis adalah dengan menggunakan model atau metode lain untuk memprediksi harga komoditas, kemudian membandingkan akurasi dari model-model tersebut 
terhadap metode ARIMA-GARCH yang telah diusulkan oleh penulis. Model prediksi harga komoditas yang memberikan akurasi tertinggi adalah model yang terbaik.

\section{REFERENSI}

Abledu, G, K, and Agbodah, K., "Stochastic Forecasting and Modeling of Volatility Oil Prices in Ghana using ARIMA Time Series Model", European Journal of Business and Management, Vol 4, No.16, 2012

Bolerslev, T., "Generalized Autoregressive Conditional Heteroskedasticity. Journal of Ecoometrics. 307-327., 1986

Box, G. E. P and Jenkins, G. M., “Time Series Analysis”, Prenticehall, 1994

Faustina, R. S., "Model Hybrid ARIMA-GARCH untuk Estimasi Volatilitas Harga Emas Menggunakan Software R". Universitas Negeri Semarang, 2016

Guha, B and Gautam B., "Gold Price Forecasting Using ARIMA Model”. Journal of Advanced Management Science Vol. 4, No. 2, March 2016

Gross G. and Galiana, F. D., “Short-Term load forecasting,” 1987, Proc. IEEE, vol. 75, no. 12, pp. 1558-1573.

K. Puspatika dan Y. Kusumawati, "Peramalan Harga Cabai Dengan Metode Arima Arch-Garch Dan Single Moving Average Di Kota Semarang," Journal of Information System, Vol 03, No 02 Nopember 2018

KumarMahto A., Biswas R., Alam M.A., Short Term Forecasting of Agriculture Commodity Price by Using ARIMA: Based on Indian Market. In: Singh M., Gupta P., Tyagi V., Flusser J., Ören T., Kashyap R. (eds) Advances in Computing and Data Sciences. ICACDS 2019. Communications in Computer and Information Science, vol 1045. Springer, Singapore

Muttaqiena, A., "Trading Komoditas Untuk Memperkaya Portofolio". Akses di website www.seputarforex.com/amp/artikel/trading-komoditas-untuk-memperkaya-portofolio-227199-33 (diakses 3 Maret 2020)

Nochai, R, and Titida, N., "ARIMA Model for Forecasting Oil Palm Price". 2006. Thailand.

Suhartono, "Analisis Data Statistika dengan R". Lab. Statistik Komputasi. ITS, Surabaya, 2008

Weiss, E. "Forecasting commodity prices using ARIMA," Technical Analysis of Stocks \& Commodities, vol. 18, no. 1 , pp. $18-19 ., 2000$ 